\title{
The invention of a beautiful old age: in search of a freer, happier life
}

For more than three decades I have been studying the words, behavior and values of Brazilian women based on the results of my research with 5,000 women and men aged between 18 and 98 years.

One of the most interesting findings relates to the relationship between happiness and age. Studies by economists with more than two million people in 80 countries have found a "happiness curve" in the shape of the letter $\mathrm{U}$ : happiness is highest in the early years of life, declines over time, reaches its lowest ebb at around 45 years of age, and then begins to grow.

I also found a "happiness curve" among the women I investigated. Those aged between 35 and 45 are the most dissatisfied, frustrated, and exhausted. They complain mostly of a lack of time, recognition and freedom. Some even say they're "missing everything"!

When I asked them what they envy most in men, the most frequent answer was freedom. When I asked what they envy in other women, they said their bodies, beauty, youth, slimness and sensuality. The body type they envied was young, slim and sexual. In Brazil, this type of body is considered a genuine asset.

Brazilian women are among the world's biggest consumers of plastic surgery, botox, facial fillers, hair dye, diet pills, appetite suppressants, sleeping pills and anxiolytics. They are the most dissatisfied with their bodies and those who most frequently stop leaving the house, going to parties and even working when they feel old, fat and ugly.

In The Beauty Myth, based on numerous surveys and much statistical data, Wolf ${ }^{1}$ describes the most important issues for women. How can we be free if we are prisoners of the idea of a perfect body? How can we be happy if we are permanently exhausted, insecure and dissatisfied with our own bodies? How can we take pleasure in mutilating and sacrificing ourselves to have a young, slim, sexy body? Wolf ${ }^{1}$ argues that every woman should have the right to choose how she wants to look and be rather than following the ideals that market forces and the multibillion-dollar advertising industry impose.

It is true that Brazilian women have largely emancipated themselves from the old servitudes of sex, childbearing and dress. Today, however, their bodies are subjected to an increasingly imperative and anxietygenerating aesthetic coercion. They are experiencing a true identity crisis: while they have achieved greater independence and freedom there is also a great degree of control over the female body.

A young body without undesirable marks (wrinkles, stretch marks, cellulite) or excesses (fat, sagging) is the only one that, even without clothing, is considered decently dressed.

But I've found that everything starts to improve after the age of 50 and the happiness curve starts to rise. From this age onwards women begin to feel much freer and happier. Why? 
First, they have discovered that time is a true asset and they cannot nor do not want to waste it. Younger women want to please and take care of everyone and complain that they have no time for themselves. Older women, meanwhile, learn to say no and begin to prioritize time to care for themselves. Learning to say no is a true revolution for women.

They also learned to carry out an existential cleansing. Cleansing is not just throwing away clothes that no longer fit, the junk, the things we no longer need. Existential cleansing is to remove those who do us only harm, only criticize, only suck our energy: true emotional vampires.

The women talked a lot about the importance of friends. It is they who care, who listen, who talk, who take them to the doctor, who call every day to find out how they are. When I asked "who will take care of you in old age?" the most common answer was "myself" followed by "my friends". When I asked men the same question they said "my wife, my daughters and my granddaughters".

In my book Coroas ("Older Women") ${ }^{2}$ I explain how, just like the subjects of my research, I also had a major crisis when I turned 40 . For the first time in my life, I went to a dermatologist for moisturizer and sunscreen, things I had never used before. After a brief skin examination, she looked closely at my face and asked: "Why don't you get an eyelid lift? They're very droopy. You'll look ten years younger." Without giving me time to respond, she continued: "Why don't you get some filler around your lips? And botox on your forehead to get rid of the wrinkles? It'll rejuvenate you by ten years."

I paid the expensive bill, which turned out to be even more pricey as it triggered a crisis that lasted almost a year. "Do I get eyelid surgery? And lip filler? And botox on my forehead? If I do everything she tells me, I'll look ten years younger. I'm guilty of getting old. It's my fault!"

I found the best way of freeing myself from the panic of getting old was to learn to laugh at my fears and insecurities. So I wrote Manifesto das Coroas Poderosas ("The Powerful Older Women's Manifesto"). In it, I argue that maturity is a phase where we achieve freedom, security, charm, success, recognition, respect, independence, pleasure, self-knowledge and more. We finally have time for ourselves: time to laugh, to dance, to travel, to study, to date, to take care of our health, to enjoy our friends, to be ourselves and not frantically respond to the expectations of others. We can display our bodies without fear of the looks of men and women, without feeling ashamed of our imperfections. We learn that every woman is unique and special ${ }^{3}$.

Today, like the women over 60 I studied for my book $A$ bela velhice ("A Beautiful Old Age") 4 , I can categorically state: "this is the best moment of my whole life. I've never been so happy. It's the first time I can be myself. I've never been so free".

Why, then, must we wait so long to discover that the best recipe for happiness is freedom? And that laughing a lot, especially at ourselves, is always the best medicine?

Mirian Goldenberg

Universidade Federal do Rio de Janeiro, Departamento de Antropologia Cultural.

Rio de Janeiro, RJ, Brazil.

\section{REFERENCES}

1. Wolf N. O mito da beleza: como as imagens de beleza são usadas contra as mulheres. Rio de Janeiro: Rosa dos Tempos; 2018.

2. Goldenberg M. Coroas: corpo, envelhecimento, casamento e infidelidade. Rio de Janeiro: Record; 2008.

3. Goldenberg M. Manifesto das Coroas Poderosas. Época [Internet]. 09 ago 2013 [acesso em 25 set. 2018]:Coluna Ruth de Aquino. Disponível em: https://epoca.globo.com/colunas-e-blogs/ruth-de-aquino/noticia/2013/08/o-manifestodas-coroas-poderosas.html

4. Goldenberg M. A bela velhice. Rio de Janeiro: Record; 2013. 